\section{THE APPROACHING ECLIPSE}

$T \mathrm{HE}$ accompanying illustration from $L a$ Nature shows the instruments to be used at the total eclipse of May 6, by M. Janssen, who has command of the French expedition. The illustration is after a photograph taken at M. Janssen's Observatory at Meudon. The French expedition, which has probably reached its destination, will be losated on Sable Island, near Caroline Island, in the Marquesas Archipelago. Before quitting Paris, M. Janssen had all his instruments and tents erected in order to see that all worked well. The frame surrounding the

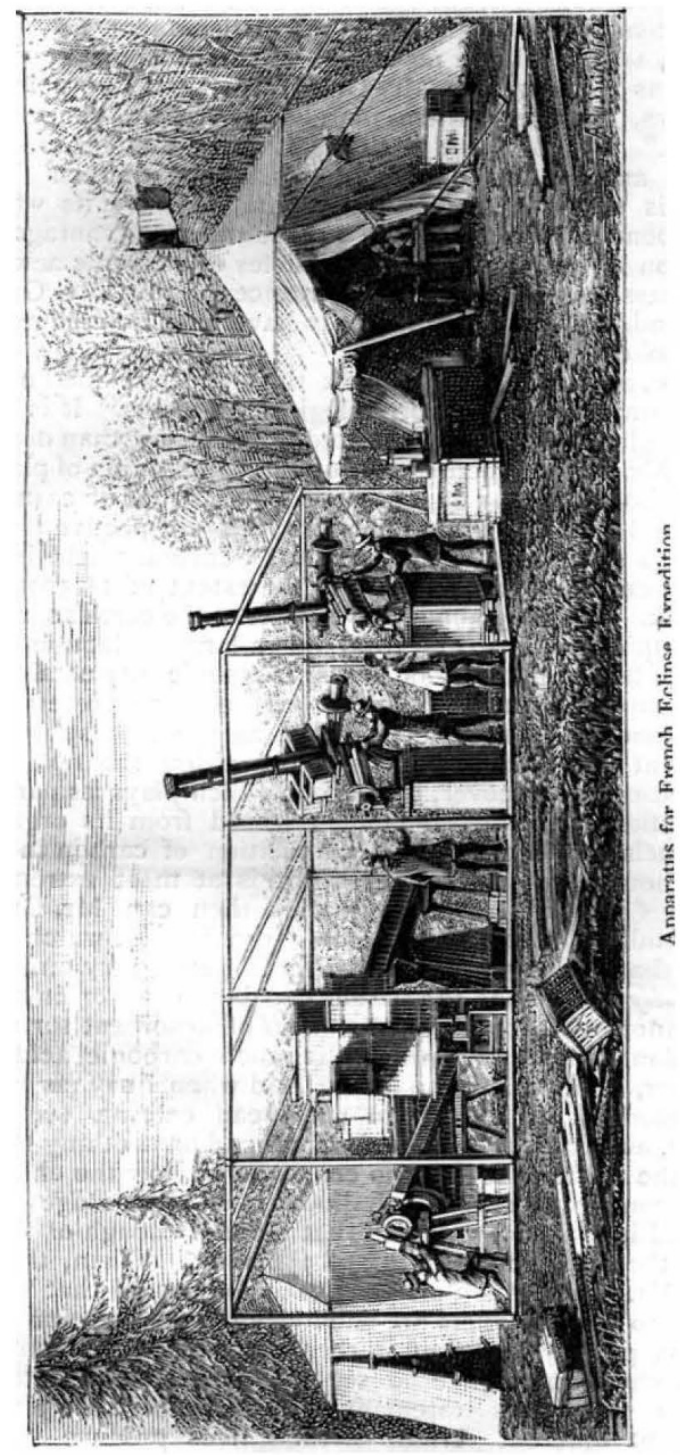

apparatus is arranged to receive a large awning to protect them. The tent on the right is intended for the astronomers, the furniture consisting of a work-table, several camp-stools, and three beds. The little tent on the left is for photography. The instruments of the French expedition comprise--I. A telescope of short focus for spectroscopic work. 2. An equatorial on which will be arranged a photographic apparatus, containing five cameras which act together. The plates are $\mathrm{O}^{\mathrm{m}} \cdot 4 \mathrm{O} \mathrm{by} \mathrm{o}^{\mathrm{m} \cdot 50}$; they will require an exposure of five minutes. This apparatus is intended for intra-Mercurial planets. 3. A telescope of 6 inches, with a lens of 3 inches, with photographic appa- ratus acting by means of three cameras at once. This apparatus is intended for the solar corona. 4. 'A fourth telescope, specially reserved for $M$. Trouvelot for drawings of the corona and search for intra-Mercurial planets.

\section{DEATHS FROM SNAKE BITE IN BOMBAY}

THE Report of the Sanitary Commissioner with the Government of Bombay shows that, among other causes of death in that Presidency in the year I88I, 1209 persons died from snake bite. The names of the snakes are not given, but it is probable that the cobra was the chief offender, the echis and bungarus accounting for those not slain by that snake. The monthly prevalence of deaths from this cause is interesting, as it shows at what period of the year efforts for destruction of snakes might be most effectively carried on; it also shows that there was an increase of thirty deaths on those of the preceding year; and it suggests that, however vigorous these efforts may have been, the result is not so satisfactory as could be wished, as a comparison of the deaths in $188 \mathrm{I}$ with the mean of those of five preceding years shows that (in $188 \mathrm{I}$ at least) the number had increased.

\begin{tabular}{|c|c|c|c|c|c|c|}
\hline \multirow{2}{*}{$\begin{array}{l}\text { Months. } \\
\text { January }\end{array}$} & \multirow[b]{2}{*}{$\cdots$} & \multicolumn{3}{|c|}{ Deaths in $188 \mathrm{I}$. } & \multicolumn{2}{|c|}{ Mean of five years } \\
\hline & & $\ldots$ & 39 & ... & $\ldots$ & 30 \\
\hline February & $\ldots$ & $\ldots$ & 34 & $\ldots$ & $\ldots$ & 24 \\
\hline March... & $\ldots$ & $\ldots$ & 55 & $\cdots$ & ... & 45 \\
\hline April ... & $\cdots$ & $\cdots$ & 55 & $\ldots$ & ... & 49 \\
\hline May ... & $\cdots$ & $\cdots$ & 95 & ... & $\cdots$ & 93 \\
\hline June $\ldots$ & $\cdots$ & $\cdots$ & 162 & ... & ... & 135 \\
\hline July ... & $\cdots$ & $\cdots$ & I9I & $\cdots$ & $\cdots$ & 164 \\
\hline August & $\ldots$ & $\ldots$ & I 65 & $\cdots$ & ... & 159 \\
\hline September & $\cdots$ & $\ldots$ & 161 & $\cdots$ & $\ldots$ & 160 \\
\hline October & $\ldots$ & ... & 128 & $\ldots$ & $\ldots$ & 144 \\
\hline November & $\cdots$ & ... & 80 & $\ldots$ & ... & 68 \\
\hline December & $\cdots$ & $\cdots$ & 44 & $\cdots$ & $\cdots$ & 39 \\
\hline & & & 209 & & & I I IO \\
\hline
\end{tabular}

This (in I88I) proves that one person in 13,610 of the whole population of $16,450,414$ for the twenty-four Presidency districts died from snake bite. June, July, August, September, and October are the months of greatest mortality, and it would be worth while inquiring if more vigorous efforts could not be made for the destruction of the snakes during these months, when it is presumed the creatures are more numerous and perhaps more active in their destructive work. The appearance and character of venomous as distinguished from harmless snakes ought now to be so well known in India that, whatever other difficulty may stand in the way of their destruction, absence of means of identification should not be one of the obstacles.

After all the mortality from snake bite is very small compared with that from other causes. The same able and most valuable Report shows that in the year 188I there were 272,403 deaths from fever, of which no doubt a large proportion were due to miasmatic causes. The entire death-rate from all causes amounts to 381,450 , or 23.18 per 1000 of the whole population. Against these death-rates and their preventable causes, whether from dirt, miasmata, foul water, or snake virus, the earnest endeavours of the sanitary authorities are now unremittingly directed, and it is impossible to read the Reports annually prepared by the Sanitary Commissioners without feeling impressed by their value and importance, or without a conviction that they must sooner or later have beneficial results on public health and the value of life in India.

JOSEPH FAYRER

\section{ASTRONOMICAL PHOTOGRAPHY}

THE important part that photography is likely to play in the future of astronomy renders it desirable that an opportunity should be afforded to astronomers to 